\title{
Analisis Cluster dan Seleksi Primer SSR (Simple Sequence Repeats) untuk Sifat Toleran Aluminium pada Cabai
}

\author{
Cluster Analysis and SSR (Simple Sequence Repeats) Primers Selection for \\ Aluminium Tolerance on Hot Pepper
}

\author{
Catur Herison $^{1 *}$, Rustikawati ${ }^{2}$, Ria Meita $^{3}$, dan Hasanudin ${ }^{4}$ \\ Diterima 10 Desember 2018/Disetujui 07 Januari 2020
}

\begin{abstract}
High yielding and Al tolerant variety of hot pepper is one of the best solutions to overcome the problem of low hot pepper production on acidic dry land. The identification of tolerant parents and SSR markers are useful in increasing the effectiveness of plant breeding programs to develop varieties tolerance to aluminum stress. SSR primer selection is an important initial step in development of molecular markers. The objective of this study was to determine aluminum tolerant genotypes based on the similarity of tolerance to aluminum stress and to determine SSR primers feasible in developing markers for tolerance to aluminum stress in hot pepper plants. The experiment was conducted to evaluate the tolerance of 27 hot pepper genotypes to aluminum stress employing a wick system hydroponic with $A B$ mix nutrient supplemented with 500 ppm $\mathrm{AlCl}_{3} .6 \mathrm{H}_{2} \mathrm{O}$. The next step is to evaluate $20 \mathrm{SSR}$ primers in amplifying representative tolerant and sensitive DNA genome. The cluster analysis on the tolerance characteristics of 27 hot pepper genotypes resulted in 7 groups of aluminum tolerance. Genotypes of PBC396 and PBC518 were very tolerant to aluminum stress and were unique so that they were the most prospective parents in the development of aluminum tolerant cultivars. SSR primers of TMS7 and CAMS358 were potential to produce polymorphic markers for tolerance to aluminum stress in hot pepper. The primers must then be further tested on the DNA genome of mapping population to determine the ones which can be used as a marker for aluminium tolerance.
\end{abstract}

Keywords: Capsicum annuum, NTSYS, grouping assessment, adaptive to acidic

\begin{abstract}
ABSTRAK
Perakitan varietas unggul cabai merah toleran $\mathrm{Al}$ (Aluminium) merupakan solusi terbaik untuk mengatasi persoalan rendahnya produkvitas cabai di lahan kering masam. Identifikasi tetua toleran dan marka SSR (Simple Sequence Repeats) sangat bermanfaat dalam meningkatkan efektifitas program pemuliaan tanaman untuk merakit varietas toleran terhadap cekaman aluminium. Seleksi primer SSR adalah bagian awal yang penting dalam pengembangan marka molekuler tersebut. Penelitian bertujuan untuk menentukan kelompok genotipe toleran alumunium dan menentukan primer prospektif dalam pengembangan marka SSR untuk sifat toleran terhadap Al pada tanaman cabai. Evaluasi tingkat toleransi 27 genotipe cabai terhadap cekaman aluminium dilakukan menggunakan hidroponik sistem sumbu dengan larutan hara $\mathrm{AB}$ mix ditambah $500 \mathrm{ppm} \mathrm{AlCl}_{3} \cdot 6 \mathrm{H}_{2} \mathrm{O}$. Tahap selanjutnya adalah menguji 20 primer SSR dalam mengamplifikasi DNA genom cabai toleran dan peka yang mewakili. Hasil analisis cluster sifat toleransi terhadap 27 genotipe cabai menghasilkan 7 kelompok tingkat toleransi terhadap aluminium. Individu PBC396 dan PBC518 adalah genotipe yang sangat toleran terhadap cekaman aluminium yang unik sehingga keduanya sangat baik digunakan sebagai tetua dalam pengembangan cabai toleran aluminium. Primer SSR yang potensial menghasilkan marka polimorfik untuk sifat toleran terhadap cekaman aluminium pada cabai adalah TMS7 dan CAMS358. Primer tersebut selanjutnya harus diuji pada mapping population untuk menentukan pita yang dapat digunakan sebagai penanda toleransi terhadap aluminium.
\end{abstract}

Kata kunci: Capsicum annuum, NTSYS, sidik gerombol, tenggang masam

${ }^{1}$ Fakultas Pertanian, Universitas Bengkulu

Jl. WR Supratman, Kandang Limun, Bengkulu 38371

E-mail : catur_herison@unib.ac.id (*penulis korespondensi) 


\section{PENDAHULUAN}

Semakin berkurangnya lahan subur, sekarang ini lahan sub-optimal bercekaman menjadi alternatif untuk meningkatkan produksi berbagai jenis tanaman. Lahan kering marginal di Indonesia didominasi oleh tanah asam, terutama jenis tanah Ultisol, yang menyumbang sekitar 25\% dan hampir 48000 000 ha (Prasetyo dan Suriadikarta, 2006). Ultisol ditandai oleh tingkat keasaman tanah yang tinggi, $\mathrm{Al}^{+}$yang tinggi dan ketersediaan nutrisi $\mathrm{P}$ yang rendah, bahan organik yang rendah, dan secara keseluruhan tingkat kesuburannya rendah (Ifansyah, 2014). Kelarutan ion aluminium di dalam tanah yang tinggi menyebabkan tanaman tidak dapat tumbuh dengan baik.

Cekaman aluminium pada berbagai tanaman menghambat pertumbuhan dan mengganggu produktivitas. Pada tanaman cabai, produktivitas tanaman di lahan masam ultisol jauh lebih rendah dibandingkan dengan di lahan andosol (Herison et al., 2017). Oleh karena itu, untuk mendapatkan produksi yang tinggi pada tanah masam dibutuhkan aplikasi bahan pembenah tanah (Choudhary dan Kumar, 2015; Putri, 2016; Hartatik dan Purwani, 2017; Lestari et al., 2017). Cekaman aluminium secara efektif dapat dikurangi melalui peningkatan $\mathrm{pH}$ tanah dengan aplikasi kapur (Bhargavaramireddy dan Subramanian, 2016). Namun demikian, aplikasi kapur untuk menyeimbangkan $\mathrm{pH}$ tanah secara teknis tidak mudah dan tidak ekonomis terutama pada wilayah yang jauh dari sumber kapur. Oleh karena itu, penelitian yang berfokus pada peningkatan sifat genetik tanaman untuk toleran terhadap cekaman aluminium sangat dibutuhkan.

Program pemuliaan untuk merakit varietas toleran cekaman alumunium memerlukan informasi genetika toleransi terhadap aluminium dan tetua toleran. Toleransi terhadap alumunium dikendalikan secara kuantitatif (Abate et al., 2013) yang berarti terdapat banyak gen yang berkontribusi terhadap sifat toleransi tersebut. Gen-gen pengendali sifat toleran tersebut kemungkinan terdapat pada tetua-tetua yang berbeda. Pemilihan tetua-tetua yang memiliki kekerabatan genetik yang jauh dibutuhkan untuk mengumpulkan sifat yang berbeda dari berbagai tetua (Zhu et al., 2015).
Karakter genotipe toleran atau peka secara fenotipik sangat dipengaruhi lingkungan. Di sisi lain, karakterisasi molekuler lebih akurat karena dapat dapat mengidentifikasi perbedaan pada tingkat lokus. Salah satu penanda molekuler yang sering digunakan dalam pemuliaan tanaman adalah Simple Sequence Repeats (SSR). SSR adalah sekuen berulang DNA yang mewakili bagian signifikan dari genom eukariot dan dapat menyajikan penanda genetik yang dapat mendeteksi perbedaan antar genotipe. SSR dapat dikerjakan relatif cepat, sederhana, bersifat polimorfik, kodominan dan stabil (Swapna dan Srivastava, 2012). SSR telah digunakan untuk mempelajari variasi dan karakteristik genotipe dalam program pemuliaan tanaman padi (Prabakaran et al., 2010; Sajib et al., 2012); gandum (Sehgal et al., 2012) dan buncis (Silva et al., 2003). SSR juga telah terbukti dapat mendeteksi ketahanan tanaman tomat terhadap penyakit layu Fusarium (Parmar et al., 2013), dan ketahanan terhadap penyakit blas pada tanaman padi (Ashkani et al., 2011).

Studi terdahulu terkait kekerabatan genetik pada umumnya dilakukan menggunakan karakter morfologi dan marka molekuler SSR (Agyare et al., 2016; Baba et al., 2016; Carvalho et al., 2017; Herison et al., 2018; Sharmin et al., 2018). Namun sangat sedikit informasi penggunaan karakter toleransi terhadap aluminium dalam studi kekerabatan genetik. Penelitian ini bertujuan untuk mengelompokkan genotipe-genotipe berdasarkan kemiripan sifat toleransi terhadap cekaman aluminium dan menentukan primer SSR yang layak untuk pengembangan marka molekuler yang dapat mendeteksi sifat toleran cekaman aluminium pada cabai merah.

\section{BAHAN DAN METODE}

Penelitian dilakukan di rumah kaca Jurusan Budidaya Pertanian Fakultas Pertanian, Universitas Bengkulu, dan analisis molekuler di Laboratorium Agronomi, Fakultas Pertanian dan Laboratorium Molekuler Fakultas Kedokteran, Universitas Bengkulu. Penelitian dimulai bulan September 2017 sampai April 2018. 


\section{Assay Cekaman Aluminium}

Media tanam yang digunakan adalah pasir kali yang dicuci bersih, kemudian dimasukkan ke dalam bak media yang diberi sumbu kapiler yang dihubungkan dengan bak penampung larutan hara (Wick system hydroponic) (Kuntz, 2013). Bak media maupun bak penampung larutan hara berbentuk persegi panjang dengan ukuran lebar $30 \mathrm{~cm}$, panjang 50 $\mathrm{cm}$ dan tinggi $20 \mathrm{~cm}$. Bak media diletakkan di atas bak penampung larutan hara. Larutan hara yang digunakan dari larutan $\mathrm{AB}$ mix. Sebagai kontrol adalah perlakuan tanpa penambahan aluminium ke dalam media dan $\mathrm{pH}$ dipertahankan pada 6.0-6.5. Perlakuan cekaman dilakukan dengan menambahkan 500 ppm $\mathrm{AlCl}_{3} .6 \mathrm{H}_{2} \mathrm{O}$ ke dalam larutan hara, mengikuti metode Dalimunthe et al. (2015), dan $\mathrm{pH}$ larutan dipertahankan pada 4.0-4.5. Media tanaman yang digunakan berupa pasir kali yang telah dicuci bersih.

Benih dikecambahkan dalam media kertas lembab hingga muncul radikula, kemudian ditanam di nampan pembibitan hingga tumbuh kotiledon. Kecambah kemudian dipindah-tanam pada bak media dengan jarak 5 $\mathrm{cm} \times 5 \mathrm{~cm}$. Pengaturan $\mathrm{pH}$ larutan dilakukan dengan menambahkan $0.1 \mathrm{M} \mathrm{HCl}$ atau $0.1 \mathrm{M}$ $\mathrm{NaOH}$ sesuai keperluan. Pengaturan $\mathrm{pH}$ dilakukan setiap dua hari sekali. Larutan hara diganti setiap lima hari sekali. Ketika berumur empat minggu, seluruh tanaman dicabut dengan cara menyemprotkan air ke dalam media tanam hingga akar tanaman dapat diangkat tanpa kerusakan.

\section{Penentuan Indeks Toleransi terhadap Cekaman (ITC)}

Dua puluh tujuh genotipe cabai yang diuji meliputi: Tanaka Tsung (TS), PBC155, PBC622, PBC402, PBC518, PBC396, PBC401, Keriting Hitam (KH), Laris, Hot Pepper (HP), PBC157, PBC621, PBC266, PBC592, PBC140, PBC146, PBC067, Kopay, Romario, Ferosa, Mario, Lokal Payakumbuh (LPK), Sempurna, Bogota, PBC398, PBC137, dan PBC521. Jumlah tanaman uji tiap genotipe adalah 15 tanaman. Nilai rata-rata setiap variabel digunakan untuk menentukan stress tolerance index (STI) atau indeks toleransi terhadap cekaman (ITC). Variabel yang diamati meliputi tinggi tanaman, diameter batang, panjang akar, volume akar, bobot segar akar, bobot kering akar, bobot segar tanaman, bobot kering tanaman. Penentuan ITC dilakukan menggunakan rumus sebagaimana dalam penelitian El-Hashash et al. (2018).

$$
\operatorname{ITC}=\left(\mathrm{Y}_{\mathrm{n}} * \mathrm{Y}_{\mathrm{c}}\right) /\left(\mathrm{Y}_{\mathrm{n}}^{2}\right)
$$

di mana ITC, $Y_{n}$, dan $Y_{c}$ berturut-turut adalah indeks toleransi terhadap cekaman, nilai pengamatan pada kondisi tidak tercekam (kontrol) dan nilai pengamatan pada kondisi tercekam. Nilai indeks toleransi pada masingmasing peubah selanjutnya dibagi menjadi 5 kelas secara proporsional untuk menentukan sub karakter tingkat toleransi, yaitu $\mathrm{ST}=$ sagat toleran, $\mathrm{T}=$ toleran, $\mathrm{AT}=$ agak toleran, $\mathrm{P}=$ peka dan SP = sangat peka. Dari 11 karakter yang diamati diperoleh 55 sub karakter. Analisis data yang dilakukan adalah analisis cluster berdasarkan UPGMA (Unweighted Pair Group Method with Arithmetic Mean).

\section{Analisis SSR}

Analisis SSR dilakukan terhadap DNA cabai yang mewakili kelompok toleran dan peka hasil analisis cluster. Data pita DNA yang diperoleh dari amplifikasi setiap genom genotipe terpilih ditabulasi sebagai fingerprint data individu. Analisis data dilakukan secara kualitatif dengan melihat polimorfisme pita SSR yang diperoleh pada setiap genotipe.

Isolasi DNA menggunakan metode CTAB suhu rendah melalui dua kali pemurnian DNA genom mengikuti prosedur Herison et al. (2012) dengan modifikasi penambahan PVP (polyvinylpyrrolidone) dalam proses penggerusan sampel untuk menghilangkan senyawa fenol (Kumar et al., 2015). Amplifikasi mengunakan 20 primer SSR yang terbukti dapat mengamplifikasi genom Solanaceae (Parmar et al., 2013; Haquarsum, 2016) (Tabel 1). Tahapan PCR dan visualisasi hasil elektroforesis mengikuti Haquarsum (2016). PCR dilakukan dalam 20 $\mu \mathrm{L}$ campuran reaksi yang mengandung $4 \mu \mathrm{L}$ Buffer, $0.4 \mu \mathrm{L} \mathrm{MgCl}_{2}, 0.4 \mu \mathrm{L}$ dNTP, $0.08 \mu \mathrm{L}$ KAPA $2 \mathrm{G}, 5.12 \mu \mathrm{L}$ aquabides, $5 \mu \mathrm{L}$ DNA, dan $5 \mu \mathrm{L}$ primer SSR. 
Tabel 1. Daftar primer SSR yang digunakan, urutan basa dan suhu annealing-nya

\begin{tabular}{|c|c|c|c|c|}
\hline No & Marka SSR & Repeat Sequence & Urutan Nukleotida & $\begin{array}{c}\mathrm{Ta} \\
\left({ }^{0} \mathrm{C}\right) \\
\end{array}$ \\
\hline \multirow{2}{*}{1} & \multirow{2}{*}{ TMS1 } & \multirow{2}{*}{ (AT) $8(\mathrm{GT}) 16$} & F: CGCTCCCTTTTTGAATTGAG & \multirow[t]{2}{*}{59.1} \\
\hline & & & R: TTGCTGTTGTGGTTTTCGAT & \\
\hline \multirow{2}{*}{2} & \multirow{2}{*}{ TMS2 } & \multirow{2}{*}{ (GT)41 (TA)6 (CT)9 } & F: TCTTTCATTTCATGTCACGA & \multirow[t]{2}{*}{54.7} \\
\hline & & & R: AGGAGACCTTATGATTCAAGG & \\
\hline \multirow{2}{*}{3} & \multirow{2}{*}{ TMS4 } & \multirow{2}{*}{$\begin{array}{l}\text { (CT) } 12 \text { (GATA) } 12 \text { ATAT } \\
\text { (AC) } 10\end{array}$} & F: CGATTAGAGAATGTCCCACAG & \multirow[t]{2}{*}{49.7} \\
\hline & & & R: TTACACATACAAATATACATAGTCTG & \\
\hline \multirow{2}{*}{4} & \multirow{2}{*}{ TMS6 } & \multirow{2}{*}{$(\mathrm{GATA}) 45$} & F: CTCTCTCAATGTTTGTCTTTC & \multirow[t]{2}{*}{57.5} \\
\hline & & & R: GCAAGGTAGGTAGCTAGGGA & \\
\hline \multirow{2}{*}{5} & \multirow{2}{*}{ TMS7 } & \multirow{2}{*}{ (TA)31 (GATA) 13} & F: ACAAACTCAAGATAAGTAAGAGC & \multirow[t]{2}{*}{57.2} \\
\hline & & & R: GTGAATTGTGTTTTAACATGG & \\
\hline \multirow{2}{*}{6} & \multirow{2}{*}{ TMS8 } & \multirow{2}{*}{ (GATA) 87} & F: GCGCACCCAAAGTTGAAG & \multirow[t]{2}{*}{58.0} \\
\hline & & & R: CCTCATAGGGACGCACATAC & \\
\hline \multirow{2}{*}{7} & \multirow{2}{*}{ TMS9 } & $(C \Delta \mathrm{TA}) 24$ & F: TTGGTAATTTATGTTCGGGA & 54.3 \\
\hline & & $($ GATA) 24 & R: TTGAGCCAATTGATTAATAAGTT & \\
\hline 8 & TMS17 & (CАTA24 (АT) & F: AATGTAACAACGTGTCATGATTC & 50.2 \\
\hline 8 & IMSI/ & (GAIA) 24 (AI)8 (GI)ZJ & R: AAGTCACAAACTAAGTTAGGG & \\
\hline 9 & SSR-67 & (AGA) 2(AAG)7 & F: GCACGAGACCAAGCAGATTA & 59.0 \\
\hline 9 & SSR-6/ & $(A G A) 2(A A G) /$ & R: GGGCCTTTCCTCCAGTAGAC & \\
\hline 10 & Tom-144 & (TAT) 15 (TGT) 4 & F: CTGTTTACTTCAAGAAGGCTG & 54.1 \\
\hline 10 & Tom-144 & (TAT)15 (TGI)4 & R: ACTTTAACTTTATTATTGCGACG & \\
\hline 11 & & (TG) 14 TT(TG) 3 & F: TGTTGAGGCTTGGGAAAAAC & 55.0 \\
\hline 11 & CAMS 024 & (TG) $14 \mathrm{TT}(\mathrm{TG}) 3$ & R: CAAGATAATGGGTAGAAAGGCAAC & \\
\hline & & & F: TTGTGGAGGAAACAAGCAAA & 55.0 \\
\hline 12 & CAMS 117 & (TG)21(TA)3 & R: CCTCAGCCCAGGAGACATAA & \\
\hline & & & F: CCCGAATCCAAGTCATTGAG & 55.0 \\
\hline 13 & CAMS 191 & (AC) $10 \mathrm{~A}(\mathrm{TA}) 4$ & R: TAAATCCGGTTCCCTTTCCT & \\
\hline 14 & CAMS & $(\Delta C) 4 \Delta \mathrm{T}(\Delta C) \&(\Delta \mathrm{T}) 2$ & F: CTCACGAGCCACTTGAACAC & 55.0 \\
\hline 14 & $207-2$ & $(\mathrm{AC}) 4 \mathrm{AT}(\mathrm{AC}) 8(\mathrm{AT}) 3$ & R: GCCTTGTTTCCTATCCCAAC & \\
\hline & CAMS 358 & (TG) 7 & F: GACCCTTCTCСССТTTTTCTT & 55.0 \\
\hline 15 & CAMS 358 & (TG) 7 & R: CACATGGACGGATCCTTTTT & \\
\hline & & & F: GAAAATCGACCCGTTTTGAA & 51.0 \\
\hline 16 & CAMS 309 & $(\mathrm{GA}) 12$ & R: TCAATTCGGACAAAATTAGCAA & \\
\hline 17 & CACCEL1 & (AT) 16 & F: CTCTAATAGGCAATAGCTCACATGC & 51.0 \\
\hline 17 & i & (AT) 16 & R: GCAGTCTCCCAGAACGTTGTCC & \\
\hline 18 & SIM6 49 & TA) 24 & F: ATTGATGGATTGGCGTTCTC & 51.0 \\
\hline & SLM6 49 & TA) 24 & R: AAAATCAGGGGTGAATTTAACG & \\
\hline 19 & CM 0011 & $(\mathrm{AC}) 5(\mathrm{TA}) 8$ & F: TCTGCTTTAAAAACACATACAT & 51.0 \\
\hline & CM OOH & & R: CATTCTTAACTGAAATTGCATG & \\
\hline 20 & $\mathrm{CA}$ & $(\mathrm{CCG}) 6$ & F: ATCTATTTTCCTCCGGCGAC & 51.0 \\
\hline 20 & 514272 & 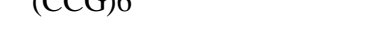 & R: CGGTAAGCTGCCTTGATCTC & \\
\hline
\end{tabular}

Keterangan: $\mathrm{F}=$ forward, $\mathrm{R}=$ reverse.

Tahapan PCR meliputi pre denaturasi pada suhu $94{ }^{\circ} \mathrm{C}$ selama 5 menit, 45 kali siklus yang terdiri: denaturasi pada suhu $94{ }^{\circ} \mathrm{C}$ selama 55 detik, annealing pada suhu sesuai primer selama 30 detik, dan elongasi pada suhu $72{ }^{\circ} \mathrm{C}$ selama 1 menit, dan terakhir berupa elongasi akhir selama 10 menit pada suhu $72{ }^{\circ} \mathrm{C}$. Hasil amplifikasi dielektroforesis horizontal menggunakan agarose $1.5 \%$ dan buffer TAE $0.5 \%$ dengan tegangan 90 volt selama 50 menit. Pewarnaan dilakukan menggunakan ethidium bromide dan visualisasi menggunakan $U V$ transluminator.

\section{HASIL DAN PEMBAHASAN}

Toleransi terhadap Cekaman Alumunium pada Cabai

Hasil penghitungan indeks toleransi terhadap cekaman (ITC) pada setiap peubah menunjukkan bahwa dalam 27 genotipe yang diuji terdapat variasi tingkat toleransi yang cukup tinggi berkisar antara $15.0 \%-81.8 \%$ (Tabel 2). Variasi tingkat toleransi yang termasuk dalam kelompok rendah diperoleh pada peubah tinggi tanaman, jumlah daun, kehijauan daun, diameter batang dan panjang akar. Variasi sedang diperoleh pada peubah 
volume akar dan luas daun. Variasi yang tinggi diperoleh pada bobot segar akar, bobot segar tajuk, dan bobot segar tanaman. Sedangkan variasi yang sangat tinggi diperoleh pada bobot kering tanaman.

Nilai indeks toleransi pada setiap peubah yang diamati juga menggambarkan bersarnya penurunan hasil pengamatan akibat cekaman alumunium. Tinggi tanaman mengalami penurunan akibat cekaman aluminium berkisar dari $46 \%$ (IT=0.54) hingga $72 \%$ (IT=0.28). Penurunan yang paling tinggi terlihat pada genotipe Bogota dan yang paling rendah pada Tanaka Tsung. Berdasarkan pada peubah jumlah daun, Lokal Payakumbuh dengan penurunan jumlah daun terendah yaitu hanya $16 \% \quad(\mathrm{IT}=0.84)$, sedangkan genotipe PBC402 adalah yang paling peka karena penurunan jumlah daun berkurang hingga $58 \%$ $\mathrm{IT}=0.42$ ).

Pada beberapa genotipe, cekaman aluminium ternyata menyebabkan peningkatan kehijauan daun, sebagaimana terlihat pada genotipe PBC622, PBC592,
Mario, dan PBC396 dengan nilai indeks toleransi terhadap cekaman lebih besar dari 1, sedangkan genotipe PBC621 mengalami penurunan kehijauan daun terbesar yaitu $37 \%$. Berdasarkan diameter batang, genotipe Tanaka Tsung adalah yang paling toleran dengan penurunan nilai sebesar $49 \%$ dan genotipe $\mathrm{PBC} 402$ adalah yang paling peka dengan penurunan nilai hingga $75 \%$. Berdasarkan peubah panjang akar, genotipe PBC 622 adalah yang paling toleran sedangkan genotipe Bogota adalah yang paling peka. Berdasarkan peubah volume akar dan bobot segar akar, genotipe PBC396 adalah yang paling toleran, sedangkan yang paling peka berturut-turut adalah PBC 402 dan PBC398. Jika dilihat pada luas daun, bobot segar tajuk dan bobot segar tanaman, maka PBC140 adalah yang paling toleran, sedangkan PBC402 dan PBC137 adalah yang paling peka. Sedangkan berdasarkan bobot kering tanaman, maka genotipe PBC592 adalah yang paling toleran dan PBC137 adalah yang paling peka.

Tabel 2. Nilai indeks toleransi terhadap cekaman alumunium 27 genotipe cabai

\begin{tabular}{|c|c|c|c|c|c|c|c|c|c|c|c|}
\hline Genotipe & TT & JD & KD & DB & PA & VA & BSA & BST & BSTan & BKTan & LD \\
\hline PBC067 & 0.31 & 0.72 & 0.81 & 0.44 & 0.71 & 0.33 & 0.30 & 0.14 & 0.15 & 0.07 & 0.12 \\
\hline PBC137 & 0.30 & 0.61 & 0.92 & 0.27 & 0.64 & 0.25 & 0.10 & 0.05 & 0.05 & 0.01 & 0.15 \\
\hline PBC140 & 0.49 & 0.65 & 0.84 & 0.45 & 0.91 & 0.75 & 0.13 & 0.36 & 0.42 & 0.10 & 0.37 \\
\hline PBC146 & 0.41 & 0.73 & 0.78 & 0.41 & 0.67 & 0.30 & 0.11 & 0.13 & 0.12 & 0.04 & 0.20 \\
\hline PBC155 & 0.34 & 0.65 & 0.72 & 0.32 & 0.82 & 0.44 & 0.43 & 0.15 & 0.16 & 0.05 & 0.13 \\
\hline PBC 157 & 0.33 & 0.45 & 0.92 & 0.35 & 0.78 & 0.34 & 0.19 & 0.11 & 0.12 & 0.04 & 0.14 \\
\hline PBC266 & 0.37 & 0.64 & 0.72 & 0.45 & 0.84 & 0.28 & 0.17 & 0.16 & 0.16 & 0.03 & 0.08 \\
\hline PBC396 & 0.42 & 0.73 & 1.03 & 0.40 & 0.88 & 0.76 & 0.78 & 0.25 & 0.28 & 0.08 & 0.25 \\
\hline PBC398 & 0.39 & 0.61 & 0.70 & 0.26 & 0.52 & 0.30 & 0.06 & 0.08 & 0.08 & 0.02 & 0.19 \\
\hline PBC401 & 0.36 & 0.81 & 0.82 & 0.38 & 0.72 & 0.37 & 0.27 & 0.11 & 0.12 & 0.02 & 0.09 \\
\hline PBC402 & 0.31 & 0.42 & 0.83 & 0.25 & 0.58 & 0.20 & 0.15 & 0.07 & 0.07 & 0.02 & 0.07 \\
\hline PBC518 & 0.35 & 0.69 & 0.83 & 0.41 & 0.72 & 0.62 & 0.41 & 0.19 & 0.21 & 0.06 & 0.20 \\
\hline PBC521 & 0.37 & 0.71 & 0.89 & 0.37 & 0.75 & 0.32 & 0.34 & 0.16 & 0.17 & 0.04 & 0.24 \\
\hline PBC592 & 0.45 & 0.71 & 1.12 & 0.42 & 0.50 & 0.42 & 0.48 & 0.34 & 0.35 & 0.23 & 0.25 \\
\hline PBC621 & 0.31 & 0.44 & 0.63 & 0.31 & 0.64 & 0.34 & 0.08 & 0.12 & 0.15 & 0.06 & 0.16 \\
\hline РBC622 & 0.32 & 0.80 & 1.17 & 0.41 & 0.91 & 0.43 & 0.30 & 0.10 & 0.11 & 0.04 & 0.19 \\
\hline BOGOTA & 0.28 & 0.54 & 0.86 & 0.30 & 0.49 & 0.34 & 0.26 & 0.13 & 0.14 & 0.06 & 0.15 \\
\hline FEROSA & 0.34 & 0.58 & 0.64 & 0.41 & 0.61 & 0.23 & 0.14 & 0.10 & 0.11 & 0.03 & 0.15 \\
\hline Hot Pepper & 0.32 & 0.53 & 0.92 & 0.27 & 0.63 & 0.25 & 0.13 & 0.11 & 0.11 & 0.04 & 0.13 \\
\hline K. Hitam & 0.39 & 0.60 & 0.89 & 0.36 & 0.79 & 0.31 & 0.28 & 0.15 & 0.16 & 0.04 & 0.17 \\
\hline KOPAY & 0.31 & 0.66 & 0.95 & 0.46 & 0.61 & 0.24 & 0.21 & 0.11 & 0.12 & 0.03 & 0.14 \\
\hline LARIS & 0.42 & 0.69 & 0.79 & 0.35 & 0.67 & 0.32 & 0.28 & 0.15 & 0.16 & 0.07 & 0.13 \\
\hline LPK & 0.29 & 0.84 & 0.90 & 0.33 & 0.59 & 0.23 & 0.21 & 0.18 & 0.18 & 0.09 & 0.19 \\
\hline MARIO & 0.41 & 0.61 & 1.02 & 0.35 & 0.66 & 0.24 & 0.13 & 0.06 & 0.07 & 0.01 & 0.10 \\
\hline ROMARIO & 0.40 & 0.66 & 0.93 & 0.38 & 0.52 & 0.35 & 0.43 & 0.12 & 0.14 & 0.04 & 0.18 \\
\hline SEMPURNA & 0.37 & 0.67 & 0.92 & 0.29 & 0.78 & 0.29 & 0.08 & 0.07 & 0.07 & 0.04 & 0.07 \\
\hline TS & 0.54 & 0.62 & 0.78 & 0.51 & 0.81 & 0.36 & 0.31 & 0.10 & 0.11 & 0.13 & 0.19 \\
\hline Rerata & 0.37 & 0.64 & 0.86 & 0.37 & 0.69 & 0.36 & 0.25 & 0.14 & 0.15 & 0.06 & 0.16 \\
\hline $\mathrm{CV}(\%)$ & 16.78 & 16.24 & 15.02 & 18.76 & 17.77 & 40.54 & 63.29 & 53.15 & 55.61 & 81.81 & 39.76 \\
\hline
\end{tabular}


Pada beberapa genotipe, cekaman aluminium ternyata menyebabkan peningkatan kehijauan daun, sebagaimana terlihat pada genotipe PBC622, PBC592, Mario, dan PBC396 dengan nilai indeks toleransi terhadap cekaman lebih besar dari 1 , sedangkan genotipe PBC621 mengalami penurunan kehijauan daun terbesar yaitu $37 \%$. Berdasarkan diameter batang, genotipe Tanaka Tsung adalah yang paling toleran dengan penurunan nilai sebesar $49 \%$ dan genotipe PBC402 adalah yang paling peka dengan penurunan nilai hingga $75 \%$. Berdasarkan peubah panjang akar, genotipe PBC 622 adalah yang paling toleran sedangkan genotipe Bogota adalah yang paling peka. Berdasarkan peubah volume akar dan bobot segar akar, genotipe PBC396 adalah yang paling toleran, sedangkan yang paling peka berturut-turut adalah PBC 402 dan PBC398. Jika dilihat pada luas daun, bobot segar tajuk dan bobot segar tanaman, maka PBC140 adalah yang paling toleran, sedangkan PBC402 dan PBC137 adalah yang paling peka. Sementara itu berdasarkan bobot kering tanaman, maka genotipe PBC592 adalah yang paling toleran dan PBC137 adalah yang paling peka.

Cekaman aluminium menyebabkan tanaman berkurang pertumbuhan dan produktivitasnya. Keracunan aluminium mengganggu serapan hara dan diferensiasi sel (Silva et al., 2010) sekalipun pembelahan sel meningkat (Cao et al., 2011). Keracunan aluminium juga meningkatkan ketebalan daun (Konarska, 2010) dan akar (Alvarez et al., 2012). Genotipe-genotipe yang toleran memiliki karakteristik yang relatif tidak berbeda pada kondisi tercekam dibandingkan pada kondisi tidak tercekam. Mekanisme toleransi terhadap keracunan aluminium dapat berlangsung secara eksternal, yaitu terjadi detoksifikasi $\mathrm{Al}$ akibat tanaman mengeluarkan sekresi asam oksalat dari akar, dan secara internal yaitu melalui detoksifikasi Al dengan membentuk senyawa kompleks Al dengan asam organik sehingga tidak beracun bagi tanaman dan menyimpannya di dalam vakuola (Wang et al., 2015). Kemampuan mengeluarkan senyawa oksalat yang dapat menetralisir $\mathrm{Al}$ dan kemampuan mengakumulasi Al di dalam vakuola sangat bervariasi antar spesies bahkan antar varietas dalam satu spesies yang menyebabkan tingkat toleransi yang bervariasi (Pattanayak dan Pfukrei, 2013).

Penentuan genotipe yang toleran terhadap cekaman aluminium seringkali tidak mudah karena tergantung dari peubah yang digunakan. Beberapa peneliti menggunakan peubah utama panjang akar untuk menentukan tingkat toleransi (Khu et al., 2012; Wang et al., 2015; Awasthi et al., 2017). Hal tersebut didasarkan bahwa penurunan panjang akar adalah yang paling awal teramati jika tanaman keracunan aluminium (Abate et al., 2013). Dalam penelitian ini penentuan genotipegenotipe toleran dilakukan dengan pendekatan clustering dengan UPGMA (Unweighted Pair Group Method with Arithmetic Mean) berdasarkan nilai indeks toleransi terhadap cekaman pada seluruh peubah yang diamati, dengan demikian maka seluruh peubah berkontribusi dalam menyusun nilai tingkat toleransi.

\section{Clustering Tingkat Toleransi Cabai terhadap Cekaman Aluminium}

Analisis cluster dilakukan menggunakan cara pengelompokkan Ahmad et al. (2013) tetapi dimodifikasi menggunakan data nilai STI (stress tolerance index). Analisis menggunakan program aplikasi NTSYS 2.0 dengan metode UPGMA dengan tingkat kemiripan (similarity coefficient) 72\%, 27 genotipe yang diuji mengelompok menjadi 7 kelompok. Kelompok I terdiri atas 9 genotipe yang meliputi PBC 067, Laris, PBC401, PBC521PBC146, PBC137, Keriting Hitam, Romario, dan Tanaka Tsung. Kelompok II meliputi 5 genotipe, yaitu PBC155, PBC266, PBC621, Bogota, dan Lokal Payakumbuh (LPK). Kelompok III terdiri atas 8 genotipe, yaitu PBC137, Hot Pepper (HP), PBC402, Ferosa, Kopay, PBC398, Mario, dan Sempurna. Kelompok IV hanya memiliki 1 genotipe, yaitu PBC622. Kelompok V meliputi 2 genotipe, yaitu PBC140 dan PBC592 (Gambar 1), sedangkan kelompok VI dan VII masing-masing beranggotakan 1 genotipe yaitu, secara berturut-turut, PBC518 dan PBC396. 


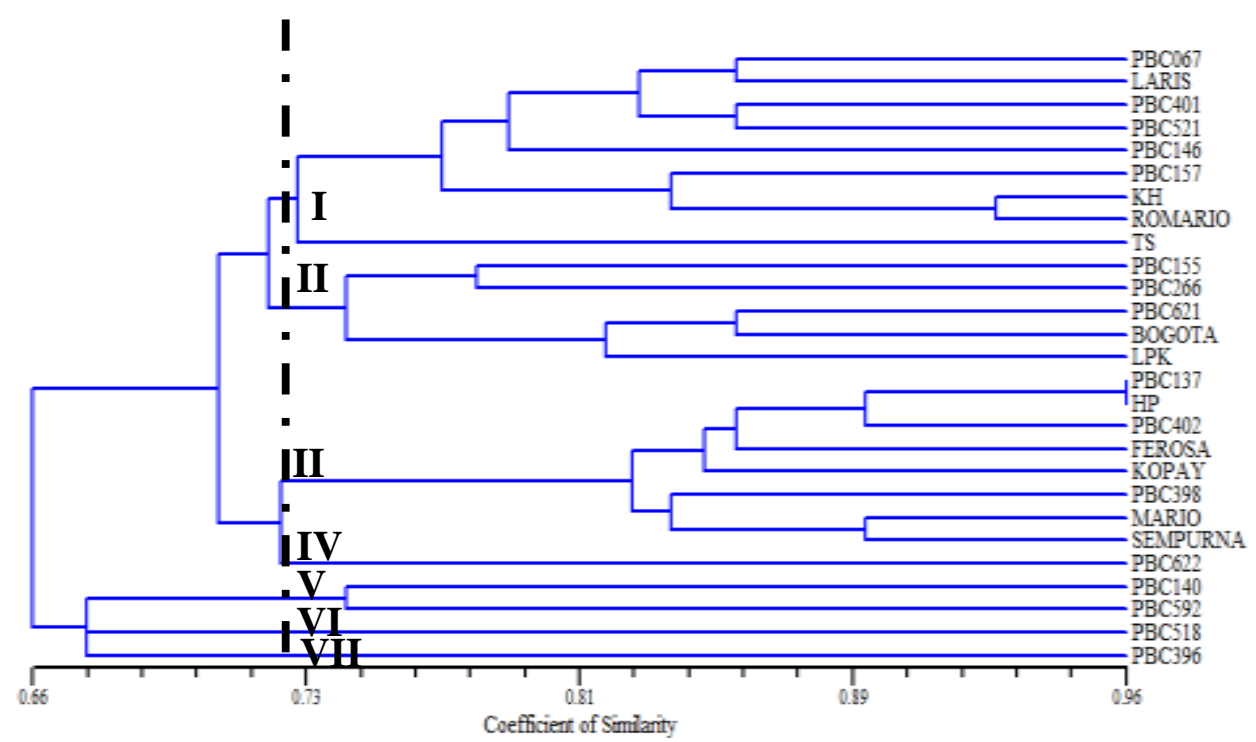

Gambar 1. Dendrogram toleransi terhadap aluminium pada 27 genotipe cabai merah

Kelompok I, II dan III adalah kelompok yang meliputi paling banyak variasi genotipe sedangkan lainnya relatif sedikit. Kelompok I dan II adalah kelompok peka, kelompok III agak toleran, kelompok IV dan V toleran dan kelompok VI dan VII sangat toleran. Hasil analisis cluster tersebut menunjukkan bahwa beberapa genotipe yang termasuk dalam kategori toleran dan sangat toleran adalah unik yang berbeda dengan genotipe lainnya. Misalnya genotipe PBC396 dan PBC518, yang membentuk kelompok yang berbeda. Genotipe sangat toleran yang unik tersebut sangat berguna sebagai tetua donor sifat toleran dalam program pemuliaan untuk merakit kultivar yang toleran terhadap cekaman (Sun et al., 2013). Toleransi terhadap cekaman aluminium dikendalikan oleh banyak gen (Abate et al., 2013) maka kemungkinan gen pengendali sifat tersebut tersebar pada beberapa genotipe tetua toleran. Menggabungkan gen toleransi dari berbagai tetua donor yang berkerabat jauh ke dalam satu genotipe melalui piramidisasi menjadi lebih efektif. Marka molekuler telah diakui sangat membantu untuk mempercepat proses seleksi dan memisahkan individu berdasarkan sifat yang secara morfologis tidak tampak. Seleksi primer merupakan tahapan yang sangat penting dalam pengembangan marka molekuler untuk sifat tertentu.

\section{Seleksi Primer SSR pada Cabai untuk Cekaman Aluminium}

Berdasarkan hasil analisis clustering (Gambar 1) ditetapkan 6 genotipe yang mewakili kelompok toleran dan peka untuk dilakukan fingerprint menggunakan marka SSR. Keenam genotipe cabai tersebut adalah PBC396 dan PBC622 yang mewakili genotipe toleran, PBC398 (agak toleran) serta Keriting Hitam, PBC146, Laris (peka). Amplifikasi menggunakan 20 primer SSR diperoleh informasi bahwa hanya 13 primer yang sesuai dengan DNA genom cabai yang diuji. Primer yang tidak sesuai untuk cabai adalah SLM649, CM0011, CA514272, TMS4, SSR-67 dan Tom144. Seluruh primer yang digunakan dalam penelitian ini telah digunakan dalam karakterisasi cabai (Ulhoa et al., 2014). Perbedaan hasil ini kemungkinan berkaitan dengan materi genetik yang berbeda.

Jumlah pita yang dihasilkan dari masingmasing primer berkisar antara 3 hingga 18 pita. Contoh visualisasi hasil amplifikasi menggunakan primer TMS 2, TMS 6, TMS 7 dan TMS 8 ditunjukkan pada Gambar 2 . Tigabelas primer SSR yang mampu mengamplifikasi DNA cabai menghasilkan 117 marka dan 38 diantaranya adalah polimorfik. Di antara marka polimorfik tersebut terdapat 25 yang polimofik untuk sifat toleran terhadap aluminium, yaitu pita muncul pada individu tanaman toleran tetapi tidak muncul pada tanaman peka. 


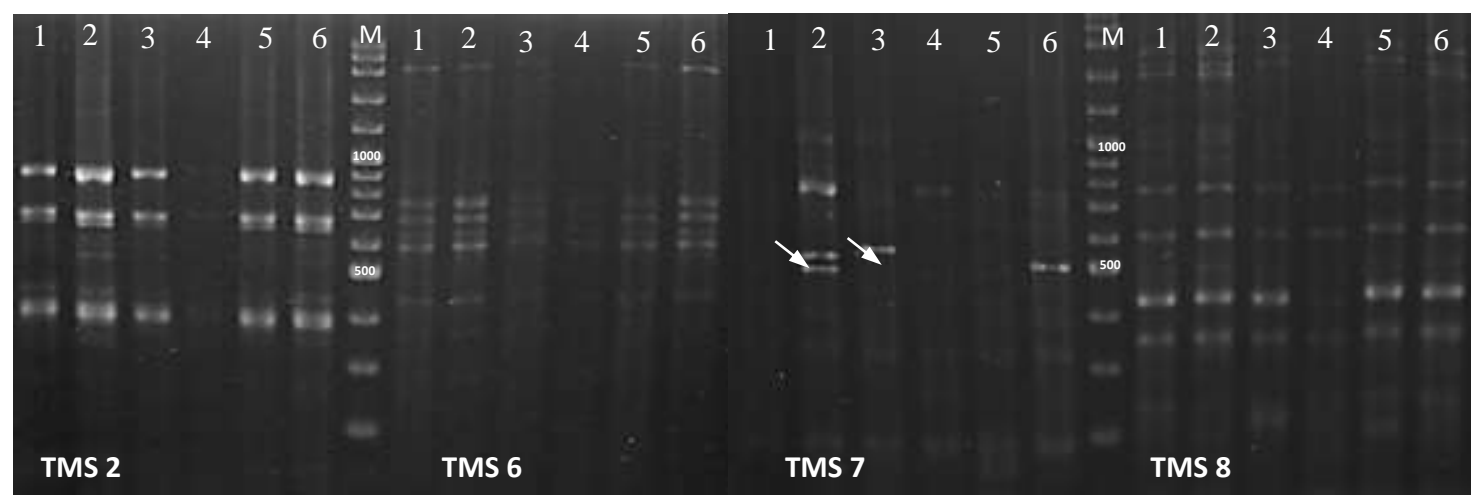

Gambar 2. Visualisasi hasil amplifikasi DNA menggunakan primer SSR TMS2, TMS6, TMS 7 dan TMS8 terhadap DNA genom cabai Keriting Hitam (1), PBC622 (2), PBC396 (3), PBC146 (4), PBC398 (5), dan Laris (6). Elektroforesis menggunakan agarose 1.5\%.

Tabel 3. Karakteristik marka SSR dari primer yang digunakan untuk mengamplifikasi DNA cabai

\begin{tabular}{lcccc}
\hline Primer & Jumlah Total Pita & $\begin{array}{c}\text { Jumlah Pita } \\
\text { Monomorfik }\end{array}$ & $\begin{array}{c}\text { Jumlah Pita } \\
\text { Polimorfik }\end{array}$ & $\begin{array}{c}\text { Jumlah Pita } \\
\text { Polimorfik Toleran }\end{array}$ \\
\hline CAMS024 & 11 & 10 & 1 & 1 \\
CAMS117 & 10 & 8 & 2 & 2 \\
CAMS191 & 7 & 7 & 0 & 0 \\
CAMS207-2 & 3 & 3 & 0 & 7 \\
CAMS358 & 14 & 5 & 9 & 0 \\
CAMS309 & 5 & 5 & 0 & 1 \\
CACCEL1i & 5 & 3 & 2 & 2 \\
TMS2 & 8 & 6 & 1 & 1 \\
TMS6 & 7 & 6 & 13 & 1 \\
TMS7 & 18 & 5 & 1 & 2 \\
TMS8 & 11 & 10 & 4 & 0 \\
TMS9 & 12 & 8 & 3 & 25 \\
TMS17 & 6 & 3 & 38 & \\
\hline Jumlah & 117 & 79 & & \\
\hline
\end{tabular}

Primer yang menghasilkan marka polimorfik toleran terbanyak adalah TMS7 yang menghasilkan 8 marka, diikuti oleh primer CAMS358 yang menghasilkan marka toleran yang banyak yaitu 7 marka (Tabel 3). Seleksi primer merupakan tahapan yang penting dalam pengembangan marka untuk membantu dalam seleksi (marker assisted selectionMAS). (Mutai et al., 2016) melakukan tahapan seleksi primer dalam upaya mengembangkan MAS untuk toleransi tanaman teh terhadap kekeringan dan (Mondal et al., 2013) pada pengembangan MAS untuk toleransi terhadap salinitas pada padi. Primer-primer yang menghasilkan marka polimorfik untuk sifat toleran selanjutnya dapat dijadikan kandidat untuk analisis bulk segregation analysis (BSA) menggunakan mapping population pada tahap selanjutnya. Dengan demikian maka, dari 20 primer yang diseleksi, TMS7 dan CAMS358 adalah primer terbaik yang berpotensi menghasilkan marka untuk toleransi terhadap cekaman aluminium.

\section{KESIMPULAN}

Analisis cluster terhadap sifat toleransi terhadap 27 genotipe cabai menghasilkan 7 kelompok yang memiliki tingkat toleransi terhadap aluminium yang berbeda. Individu PBC396 dan PBC518 adalah genotipe yang sangat toleran dan masing-masing unik. Primer SSR TMS7 dan CAMS358 adalah primer yang potensial menghasilkan marka polimorfik untuk sifat toleran terhadap cekaman aluminium pada cabai merah. 


\section{DAFTAR PUSTAKA}

Abate, E., S. Hussien, M. Laing, F. Mengistu. 2013. Aluminium toxicity tolerance in cereals: Mechanisms, genetic control and breeding methods. AJAR. 8(9): 711-722.

Agyare, R.Y., R. Akromah, M.S. Abdulaic. 2016. Assessment of genetic diversity in pepper (Capsicum sp.) landraces from Ghana using agro-morphological characters. Journal of Experimental Agriculture International. 1-16.

Ahmad, M., A. Shahzad, M. Iqbal, M. Asif, A.H. Hirani. 2013. Morphological and molecular genetic variation in wheat for salinity tolerance at germination and early seedling stage. Aus. J. Crop Sci. 7(1): 66-74.

Alvarez, I., O. Sam, I. Reynaldo, P. Testillano, M.C. Risueño, M. Arias. 2012. Morphological and cellular changes in rice roots (Oryza sativa L.) caused by Al stress. Bot. Studies. 53(1):67-73.

Ashkani, S., M.Y. Rafii, M. Sariah, N.A.A. Siti, I. Rusli. 2011. Analysis of simple sequence repeat markers linked with blast disease resistance genes in a segregating population of rice (Oryza sativa). Genet. Mol. Res. 10(3):13451355.

Awasthi, J.P., B. Saha, P. Regon, S. Sahoo, U. Chowra, A. Pradhan, A. Roy, S.K. Panda. 2017. Morpho-physiological analysis of tolerance to aluminum toxicity in rice varieties of North East India. PloS one. 12(4):e0176357. https://doi.org/10.1371/journal.pone.01 76357.

Baba, V.Y., K.R. Rocha, G.P. Gomes, C. de Fátima Ruas, P.M. Ruas. 2016. Genetic diversity of Capsicum chinense accessions based on fruit morphological characterization and AFLP markers. Genetic Resources and Crop Evolution. 63(8):1371-1381.
Bhargavaramireddy, C.H., K.S. Subramanian. 2016. Nano-lime for remediation of soil acidity: Synthesis and characterization. Curr. Adv. Agric. Sci. 8(1):39-43.

Cao, Y., Y. Lou, Y. Han, J. Shi, Y. Wang, W. Wang, F. Ming. 2011. Al toxicity leads to enhanced cell division and changed photosynthesis in Oryza rufipogon L. Mol. Biol. Rep. 38(8):48394846. doi: 10.1007/s 11033-010-0618-9.

Carvalho, S.I.C., L.B. Bianchetti, C.F. Ragassi, C.S.C. Ribeiro, F.J.B. Reifschneider. 2017. Genetic variability of a Brazilian Capsicum frutescens germplasm collection using morphological characteristics and SSR markers. Embrapa Hortaliças-Artigo em periódico indexado (ALICE).

Choudhary, V.K., P.S. Kumar. 2015. Amelioration of Acidic Soil and Production Performance of Cowpea by the Application of Different Organic Manures in Eastern Himalayan Region, India. Comm. Soil Sci. Plant Anal. 46(20):2523-2533. doi:10.1080/ 00103624.2015 .1081928 .

Dalimunthe, S.R., A.B. Arif, I.B. Jamal. 2015. Uji ketahanan terhadap aluminium dan $\mathrm{pH}$ rendah pada jagung (Zea mays L) varietas pioneer dan srikandi secara in vitro. J. Pert. Trop. 2(3):292-299.

El-Hashash, E.F., R.Y.A. EL-Agoury, K.M. El-Absy, S.M.I. Sakr. 2018. Genetic parameters, multivariate analysis and tolerance indices of rice genotypes under normal and drought stress environments. Asian J. Res. Crop Sci. 1(3):1-18.

Haquarsum, E.J.V. 2016. Seleksi dan Studi Pewarisan serta Pengembangan Marka SSR Penanda Ketahanan terhadap Penyakit Layu Bakteri (Ralstonia Solanacearum) pada Tomat. Tesis. http://repository.ipb.ac.id/xmlui/handle /123456789/82697 (8 Desember 2018). 
Hartatik, W., J. Purwani. 2017. Peningkatan produktivitas kedelai (Glycine max L.) pada Typic Kanhapludults dengan aplikasi pembenah tanah dan pupuk NPK. J. Tanah dan Iklim. 41(2):123134. doi: 10.2017/jti.v41i2.6168.

Herison, C., M. Handajaningsih, F. Fahrurrozi, R. Rustikawati. 2017. Wet season trials on growth and yield of six newly developed chili pepper hybrids at three different locations. Ijaseit. 7(5): 19131919. doi:10.18517/ijaseit.7.5. 2515.

Herison, C., S. Winarsih, M. Handayaningsih, Rustikawati. 2012. DNA markerassisted and morphological selection on BC3 genotypes shortcut the introgression of CMV tolerance genes on chili pepper. Agrivita. J. Agric. Sci. 34(3):215-224.

Herison, C., S.H. Sutjahjo, I. Sulastrini, Rustikawati, S. Marwiyah. 2018. Genetic diversity analysis in 27 tomato accessions using morphological and molecular markers. Agrivita, J. Agric. Sci. 40(1):36-44.

Ifansyah, H. 2014. Soil pH and solubility of aluminum, iron, and phosphorus in Ultisols: the roles of humic acid. J. Tanah Trop. 18(3):203-208.

Khu, D.M., R. Reyno, E.C. Brummer, M.J. Monteros. 2012. Screening methods for aluminum tolerance in alfalfa. Crop Sci. 52(1): $\quad 161167$. doi:10.2135/ cropsci2011.05.0256.

Konarska, A. 2010. Effects of aluminum on growth and structure of red pepper (Capsicum annuum L.) leaves. Acta Physiol. Plant. 32(1):145. doi:10.1007/ s11738-009-0390-4.

Kuntz, L.B. 2013. Wick irrigation systems for subsistence farming. http://dspace.mit. edu/handle/1721.1/83726 (8 Oktober 2017).

Lestari, T., Trikusumaningtyas, S.W. Ardie, D. Sopandie. 2017. The Role of
Phosphorus in Improving Sorghum Tolerance to Aluminum Stress. J. Agron. Indonesia. 45(1):43-48.

Mondal, U., M.S.R. Khanom, L. Hassan, S.N. Begum. 2013. Foreground selection through SSRs markers for the development of salt tolerant rice variety. J. Bangladesh Agric. Univ. 11(1):67-72.

Mutai, C., S.M. Kamunya, R.C. Muoki, S. Runo, A.J. Mgutu, M. Wamalwa, T.K. Maritim, F.N. Wachira, R.K. Korir. 2016. Development of EST-SSR primers for marker-assisted selection for drought tolerance in tea (Camellia sinensis (L.) O. Kuntze). Tea. 37(1/2): 129-138.

Parmar, P., A. Sudhir, R. Preethi, B. Dave, K. Panchal, R.B. Subramanian, A. Patel, K.B. Kathiria, . 2013. Identification of a SSR marker (TOM-144) linked to Fusarium wilt resistance in Solanum lycopersicum. Amer. J. Mol. Biol. 3:241-247.

Pattanayak, A., K. Pfukrei. 2013. Aluminium toxicity tolerance in crop plants: Present status of research. African J. Biotech. 12(24):3752-3757.

Prabakaran, A., K. Paramasivam, T. Rajesh, D. Rajarajan. 2010. Molecular characterization of rice land races using SSR markers. Electron. J. Plant Breed. 1(4):512-516.

Prasetyo, B.H., D.A. Suriadikarta. 2006. Karakteristik, potensi, dan teknologi pengelolaan tanah Ultisol untuk pengembangan pertanian lahan kering di Indonesia. J. Litbang Pertanian. 25(2): 39-46.

Putri, T.N. 2016. Pengaruh Dosis Pupuk Organonitrofos Plus, Pupuk Anorganik, dan Biochar terhadap Pertumbuhan dan Produksi Tanaman Jagung Manis (Zea Mays Saccharata L.) pada Tanah Ultisols Taman Bogo. Skripsi Unila. http://digilib.unila.ac.id/id/eprint/24457. 
Sajib, A.M., M. Hossain, A. Mosnaz, H. Hossain, M. Islam, S. Ali, S.H. Prodhan. 2012. SSR marker-based molecular characterization and genetic diversity analysis of aromatic landreces of rice (Oryza sativa L.). J. BioSci. Biotech. 1(2):107-116.

Sehgal, S.A., R.A. Tahir, M. Nawaz. 2012. Molecular characterization of wheat genotypes using SSR markers. Int. J. Bioautomation. 16(2):119-128.

Sharmin, A., M.E. Hoque, M.M. Haque, F. Khatun. 2018. Molecular diversity analysis of some chilli (Capsicum spp.) genotypes using SSR markers. American Journal of Plant Sciences. 9(3):368-379.

Silva, G.F. da, J.B. dos Santos, M.A.P. Ramalho. 2003. Identification of SSR and RAPD markers linked to a resistance allele for angular leaf spot in the common bean (Phaseolus vulgaris) line ESAL 550. Genetics Mol. Biol. 26(4):459-463.

Silva, S., O. Pinto-Carnide, P. Martins-Lopes, M. Matos, H. Guedes-Pinto, C. Santos. 2010. Differential aluminium changes on nutrient accumulation and root differentiation in an $\mathrm{Al}$ sensitive vs. tolerant wheat. Environ. Exp. Bot. 68(1):91-98.
Sun, J., H. Luo, J. Fu, B. Huang. 2013. Classification of genetic variation for drought tolerance in tall fescue using physiological traits and molecular markers. Crop Sci. 53(2):647-654.

Swapna, M., M.S. Srivastava. 2012. Molecular Marker Applications for Improving Sugar Content in Sugarcane. Springer, London.

Ulhoa, A.B., T.N. Pereira, R.N. Silva, C.F. Ragassi, R. Rodrigues, M.G. Pereira, F.J. $\quad 2014$. Caracterização molecular de linhagens de pimenta do tipo jalapeño amarelo. Horticultura Brasileira 32(1):35-40. doi: 10.1590/hb.v32i01.197.

Wang, H., R.F. Chen, T. Iwashita, R.F. Shen, J.F. Ma. 2015. Physiological characterization of aluminum tolerance and accumulation in tartary and wild buckwheat. New Phytol. 205(1): 273279. doi: 10.1111/nph.13011.

Zhu, Z., X. Xu, B. Cao, C. Chen, Q. Chen, C. Xiang, G. Chen, J. Lei. 2015. Pyramiding of AtEDT1/HDG11 and Cry2Aa2 into pepper (Capsicum annuum L.) enhances drought tolerance and insect resistance without yield decrease. Plant Cell, Tissue and Organ Culture (PCTOC). 120(3):919-932. 